\title{
A LINKAGE MEASURE FRAMEWORK FOR THE REAL ESTATE SECTOR
}

\author{
Yu SONG, Chunlu LIU and Craig LANGSTON \\ School of Architecture and Building, Deakin University, Geelong, Vic 3217, Australia \\ Fax: + 61-3-52278303, E-mail: chunlu@deakin.edu.au
}

Received 22 March 2005; accepted 17 May 2005

\begin{abstract}
Linkage is one of the most important factors for gaining competitive advantage. Information on linkages is essential to understanding the structure of an economy, which is in turn important in formulating industry policies and business strategies. The hypothetical extraction method is used to measure the linkages by extracting a sector hypothetically from an economic system in the literature. In the previous research, however, the internal linkage (linkage within a sector) and sectoral linkages (linkage between two specific sectors) are ignored, and there is not a comprehensive framework to measure the linkages of a specific sector. Using the recently published Organisation for Economic Co-operation and Development input-output database at constant prices, this paper aims to resolve these two shortcomings and thereby propose a linkage measure framework to explore the linkages between the real estate sector and other sectors from a new angle. The relative and absolute linkages are termed and the total, backward, forward, internal and sectoral linkage indicators are formulated to investigate the linkages of the real estate sector from all directions. Empirical results show an increasing trend of these linkages, which confirms the increasing role of the real estate sector with economic maturity over the examined period. This framework also can be employed in other sectors.
\end{abstract}

KEYWORDS: Input-output analysis; Hypothetical extraction method; Linkage; Real estate sector; Construction sector

\section{INTRODUCTION}

Theoretically, a sector's relationships with the rest of the economy through its direct and indirect intermediate purchases and sales are described as the sector's linkages (Miller and Lahr, 2001). Linkage is one of the most important factors for gaining competitive advantage. The direction and level of such linkages present the potential capacity of each sector to stimulate other sectors. The sectors with the highest linkages should be possible to stimulate a more rapid growth of production, income and employment than with alternative allocations of resources. For example, a high linkage between a supplier and a buyer may guarantee on time delivery of inputs and the quality of the inputs. Moreover, when a sector successfully enters a foreign market, it will be relatively easy for sectors that have high linkages with this sector to gain access to the foreign market (Hoen, 2002). Information on these linkages is essential to understanding the structure of an economy, which is in turn important in formulating industry policies and business strategies (Cai and Leung, 2004). What is more, the linkages are important for the number of innovations developed in a country because there is a positive relation between the diversity of the local sector structure and the number of innovations developed by these sectors (Hoen, 2002). Originally, the early linkage effect measures were categorized into two basic groups according to 
the direction of interdependencies. One is the backward effect, which identifies how a sector depends on others for their input supplies. The other is the forward effect, which identifies how the sector distributes its outputs to the remaining economy (Hirschman, 1958). The backward and forward linkages have extensively been used for the analysis of interdependent relationships between economic sectors in order to determine appropriate development strategies. However, the linkages just from these two directions cannot reflect well the intrinsic characteristics of a sector in modern society. A comprehensive measure hence is needed.

Founded by Wassily Leontief in the late of 1930 s, the input-output analysis focuses on how inter-sector trading influences the overall demand for labour and capital within an economy (Leontief, 1936). By displaying all flows of goods and services within an economy, the input-output technology has been considered in the literature as a main tool to determine, define, measure and assess the linkages between sectors (Miller and Blair, 1985; Lean, 2001). With the linkage measures, two different countries or regions can be compared and the methods may even be used to analyse technological and energy linkages (Pietroforte and Gregori, 2003; Su et al., 2003).

Measure methods of the linkages rooted in the input-output table may be classified under two main categories, one refers to the traditional method and the other is the hypothetical extraction method (HEM). The traditional methods mainly focus on the calculations of the demand-driven model (Leontief model) and the supply-driven model (Ghosh model) proposed by Ghosh (1958). Using the traditional method, Bon (1988) first applied the linkage concept to the construction sector and Bon (2000) found that the input-output technology can be used for studying four partially overlapping aspects of the construction sector: employment creation, construction linkage, construction productivity, and change in construction technology. Pietroforte et al. (2000) discussed the construction linkages of Italy's North and South over a period of more than 30 years. Pietroforte and Gregori (2003) first used the OECD input-output tables to conduct a linkage analysis of the construction sector in eight OECD countries. Compared with construction, the linkage measure using the traditional method has a relatively short history within the field of real estate. Tse (1994) argued that the real estate service is a consumption concept whereas the real estate capital stock is an investment concept and different ways to measure service consumption will give different interpretations and results. Roulac (1996) examined the real estate financial inputoutput relationships, and Pagliari et al. (1997) compared commercial real estate output in Australia, Canada, the United Kingdom and the United States over the period 1985-1995 by separately analysing office, retail and warehouse sectors. More recently, Song et al. (2004) compared the linkages between the construction and real estate sectors. Furthermore, Liu and Song (2004) measured the real estate productivity and Liu et al. (2005) analyzed the linkages of the real estate sector and formulated a set of indicators to compare the linkages of the real estate sector in seven OECD countries based on the traditional method. However, the traditional calculation methods are being gradually ignored because they do not capture much of the inherent complexity of an economy (Miller and Lahr, 2001).

The original idea of the HEM tries to extract a sector hypothetically from an economic system and examine the influence of this extraction on other sectors in the economy (Miller and Lahr, 2001). The output differences before and after the hypothetical extraction reflect the linkages of a sector. Linkage measures based on the HEM become increasingly influential (Miller and Lahr, 2001). The HEM has been applied to the agriculture sector (Cai and Leung, 2004), the water sector (Duarte et al., 2002), and some other sectors (Dietzenbacher and Van der Linden, 1997; Yue and Andreosso-O'Callaghan, 2004). However, there are still some shortcomings in the previous HEM research. More importantly, even though the HEM studies have been applied to many sectors, no real estate linkage research uses the HEM to the best of our knowledge. It is there- 
fore necessary to fill this gap. Using the recently published Organisation for Economic Co-operation and Development (OECD) input-output database at constant prices, this paper aims to resolve the two shortcomings mentioned above and thereby propose a linkage measure framework to explore the linkage between the real estate sector and other sectors from a new angle. This paper comprises discussion of the underpinning literature, a proposed measure framework, a description of the research data, an analysis of the empirical results, and finally the conclusions of the research.

\section{UNDERPINNING LITERATURE}

The linkage measure methods may be classified under two main categories. One is the traditional method based on the input/output coefficients and the other is the Hypothetical Extraction Method.

\subsection{Traditional calculation method of the linkages}

The traditional method can be divided into two sub-categories. One is the direct backward and forward linkage measures rooted in the input or output coefficient matrixes. The other is the total backward and forward linkage measures derived from the Leontief or Ghosh inverse matrices.

Given the usual input-output system, an economy consists of $n$ sectors and the output of sector $i$ is denoted by $x_{i}(i=1, \ldots \ldots, \mathrm{n})$. The basic balance equation of demand-driven model (Leontief model) can be shown as: $X=A X+Y$, where $X$ denotes vector of gross output, $A$ denotes matrix of technical coefficients $(n \times n)$ and $Y$ denotes vector of final demand. Chenery and Watanabe (1958) argued that the direct backward linkage measure consisted of the column sums of $A$ matrix. The level of backward linkages of sector $j$ is given by the ratio of intermediate inputs $i$ purchased by $j$ and its output, namely: $\lambda A$, where $\lambda$ is a summation column vector. Similarly, the supply-driven model, that is, Ghosh model (Ghosh, 1958) can be shown as: $X=X B+V$, where, $B$ denotes direct output coefficients matrix $(n \times n), V$ denotes vector of value added. Chenery and Watanabe (1958) considered that the direct forward linkage is the row sums of $B$ matrix. The level of forward linkages of sector $i$ is given by the ratio of intermediate outputs of sector $i$ and its outputs, that is, $\lambda^{\prime} \mathrm{B}$, where $\lambda^{\prime}$ is a summation row vector.

Rasmussen (1956) adopted the concept of a multiplier to measure the total backward linkages. The Leontief model can be rearranged as: $X=(I-A)^{-1} Y$, where $I$ denotes the identity matrix, and $(I-A)^{-1}$ denotes the Leontief inverse matrix. The total backward linkage, based on the Leontief inverse matrix, can be defined as the column sums of the inverse matrix, namely, $\lambda L_{i j}$, where $L_{i j}$ is the ijth element of the Leontief inverse matrix. This total backward linkage measures the extent to which a unit changes in the final demand for the product of sector $j$ on overall output. Similarly, the Ghosh price model can be used to measure the total forward linkage and the model can be rearranged as: $X=V(I-B)^{-1}$, where $(I-B)^{-1}$ refers to the Ghosh inverse matrix. The total forward linkage, derived from the Ghosh inverse matrix, can be defined as the row sums of the inverse matrix, namely, $\lambda^{\prime} G_{i j}$, where $G_{i j}$ is the $i j$ th element of the Ghosh inverse matrix. The total forward linkage indicates the impacts on output of a unit increase in value added of $i$ sector. The traditional calculation methods have been gradually given up because it just reflects the first round of effects generated by the inter-relationships between sectors and ignores the indirect effect of inter-sectoral linkages in the production process (Miller and Lahr, 2001). 


\subsection{Hypothetical extraction method}

The original idea of the HEM was to extract a sector hypothetically from an economic system and examine the influence of this extraction on other sectors in the economy. Mathematically, the idea was to quantify how much an economy's total output would decrease if the sector were extracted. Thus, by comparing the output levels for each of the remaining sectors before and after the hypothetical extraction, the impact of the extracted sector can be assessed. The difference between the output in the reduced case and in the original situation reflects the linkages between the extracted sector and all other sectors in the economy. In light of the basic ideal of HEM, it is assumed that the n-sector input-output technical coefficient $A$ has been partitioned into two groups: group one $\left(g_{1}\right)$ is a sector that are to be extracted from the economy and group two $\left(\mathrm{g}_{2}, \mathrm{~g}_{1}+\mathrm{g}_{2}=\mathrm{n}\right)$ consists of all the remaining sectors of the economy. Now, the $g_{1}$ has been extracted hypothetically from the economy, using the same final demand vector the Leontief model can be rewritten as $X^{\prime}=\left(I-A^{\prime}\right)^{-1} Y$, where $X^{\prime}$ is the output after extraction and $A^{\prime}$ is a reduced technical coefficients matrix $((\mathrm{n}-1) \times(\mathrm{n}-1))$. The reduction in output can be expressed as $X-X$, which reflects the linkage between $g_{1}$ and $g_{2}$ given the technical production process held constant. The linkage can be decomposed into backward and forward linkages according to different transformations.

In the literature, backward and forward linkages are widely accepted concepts for describing inter-sectoral relationships, yet how to measure them remains controversial even though much research. Cella (1984) defined "total linkage", which was decomposed into total backward and forward linkages. Cella argued that his method built up an appropriate measure of "the quantities of $\mathrm{n}$ goods directly and indirectly stimulated by the intermediate functions". However, Cella's definition received a lot of criticism, which mainly focused on the decomposition of linkages and the choice of the Leontief quantity model and Ghosh price model (Clements, 1990; Dietzenbacher and Van der Linden, 1997; Cai and Leung, 2004). Following these arguments, a series of methods (transformations) were proposed, such as net linkage, absolute linkage, pure linkage and so on. Miller and Lahr (2001) reviewed all these transformations in light of the influence on output by using seven hypothetical extractions from the Leontief and Ghosh models and concluded that the total linkage derived from the HEM is an appropriate measure of an extracted sector's importance. Additionally, they suggested using the Leontief model to explore the backward linkage and the Ghosh model to measure the forward linkage. Their suggestions have been approved widely in the literature.

Nevertheless, two main shortcomings exist in the previous HEM research: firstly, the internal linkage and sectoral linkages are not investigated well because the method is used only to analyze the linkages between a specific sector and all other sectors. Most of HEM research just focused on the effect of each sector on the economic system as a whole, which is not suited well for answering questions as to how the linkages operate within a sector and between two specific sectors (Hoen, 2002). Secondly, the research lacks a comprehensive framework to measure the linkages of a specific sector because the method was used only in identifying the key sectors in an economy (Miller and Lahr, 2001). Hence, omni-directional linkage measures are needed, including total, backward, forward, internal and sectoral linkages.

\section{A PROPOSED LINKAGE MEASURE FRAMEWORK}

In this paper, using the input-output tables of 36-sectors in seven OECD counties, four extraction structures are adopted to formulate the total, backward, forward and internal linkage indica- 
tors and one structure is developed further to formulate the sectoral linkage indicators of the real estate sector, which show the linkage between the real estate sector and a specific sector. Thus, linkages of the real estate sector can be measured from all directions. According to different normalizations method, these linkage indicators are put into two categorizes as shown in Figure 1: one is termed the relative linkage indicators, which divides the linkages by the total preextraction output $\mathrm{X}$, and indicates the percentage decrease in economy-wide outputs caused by the extraction. The other is termed the absolute linkage indicators, which divides the linkages by the sectional pre-extraction output $x_{i}$ or $x_{j}$, and indicates an absolute change in sectional outputs caused by the extraction.

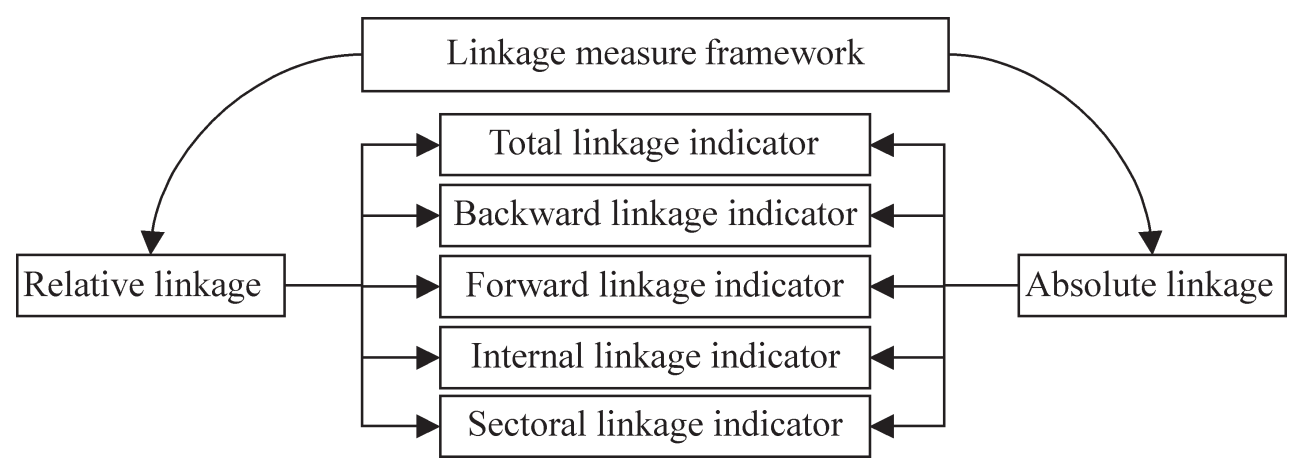

Figure 1. Linkage measure framework using the HEM

\subsection{Total linkage indicator}

In light of the basic idea of HEM, it is assumed that the n-sector input-output technical coefficient $A$ has been partitioned into two $g_{1}$ and $g_{2}$. Assuming $g_{1}=1$, then the Leontief model can be expressed as:

$$
\left[\begin{array}{l}
X_{1} \\
X_{2}
\end{array}\right]=\left[\begin{array}{ll}
A 11 & A_{12} \\
A 21 & A 22
\end{array}\right] \times\left[\begin{array}{l}
X_{1} \\
X_{2}
\end{array}\right]+\left[\begin{array}{l}
Y_{1} \\
Y_{2}
\end{array}\right]
$$

Now, the sector 1 (i.e. $\mathrm{g}_{1}$ ) is hypothetically extracted entirely from the economy. $X_{1}{ }^{\prime}$ and $X_{2}{ }^{\prime}$ denote the outputs of $g_{1}$ and $g_{2}$ after the extraction. Set $A_{11}=A_{12}=A_{21}=0$, Eq. (1) can be expressed as:

$$
\left[\begin{array}{l}
X^{\prime} 1 \\
X^{\prime} 2
\end{array}\right]=\left[\begin{array}{cc}
0 & 0 \\
0 & A 22
\end{array}\right] \times\left[\begin{array}{l}
X^{\prime} 1 \\
X^{\prime} 2
\end{array}\right]+\left[\begin{array}{l}
Y_{1} \\
Y_{2}
\end{array}\right]
$$

The difference between Eq. (1) and Eq. (2), that is the total linkage (TL), can be expressed as:

$$
T L=\left[\lambda_{1}(H-I)+\lambda_{2} \mathrm{~L}_{22} \mathrm{~A}_{21} \mathrm{H}\right] \times \mathrm{Y}_{1}+\left[\lambda_{1} H A_{12} L_{22}+\lambda_{2} L_{22} A_{21} H A_{12} L_{22}\right] \times Y_{2}
$$

where $H$ equals $\left(I-A_{11}-A_{12} L_{22} A_{21}\right)^{-1}, \lambda_{1}$ and $\lambda_{2}$ are column summation vectors for $g_{1}$ and $g_{2}$ respectively. Thus, the relative total linkage indicator can be obtained as: 
Relative total linkage indicator $=\frac{T L}{\lambda X} \times 100 \%$

The absolute total linkage indicator can be expressed as:

Absolute total linkage indicator $=\frac{T L}{x_{i}} \times 100 \%$

\subsection{Backward linkage indicator}

By assuming that sector 1 purchases import goods only to substitute completely for the local inputs, the backward linkage can be decided.

From Eq. (1), let $\mathrm{A}_{21}=0$, then,

$$
\left[\begin{array}{l}
X^{\prime} 1 \\
X^{\prime} 2
\end{array}\right]=\left[\begin{array}{cc}
A 11 & A 12 \\
0 & A 22
\end{array}\right] \times\left[\begin{array}{l}
X^{\prime} 1 \\
X^{\prime} 2
\end{array}\right]+\left[\begin{array}{l}
Y_{1} \\
Y_{2}
\end{array}\right]
$$

The difference between Eq. (1) and Eq. (6), that is the backward linkage (BL), can be defined as:

$$
B L=\left[\lambda_{1}\left(H-L_{11}\right)+\lambda_{2} L_{22} A_{21} H\right] \times Y_{1}+\left[\lambda_{1}\left(H-L_{11}\right) A_{12} L_{22}+\lambda_{2} L_{22} A_{21} H A_{12} L_{22}\right] \times Y_{2}
$$

The relative backward linkage indicator can be obtained as:

Relative backward linkage indicator $=\frac{B L}{\lambda X} \times 100 \%$

Then the absolute backward linkage indicator can be expressed as:

Absolute backward linkage indicator $=\frac{B L}{x_{i}} \times 100 \%$

\subsection{Forward linkage indicator}

The measures of forward linkage are based on the extraction of the Ghosh model. The corresponding forward linkage can be similarly obtained. The basic Ghosh model can be partitioned as:

$$
\left[\begin{array}{ll}
X_{1} & X_{2}
\end{array}\right]=\left[\begin{array}{ll}
X_{1} & X_{2}
\end{array}\right] \times\left[\begin{array}{ll}
B 11 & B 12 \\
B 21 & B 22
\end{array}\right]+\left[\begin{array}{ll}
V_{1} & V_{2}
\end{array}\right]
$$

where, $\mathrm{V}_{1}$ and $\mathrm{V}_{2}$ denote the value added of $g_{1}$ and $g_{2}$ respectively.

For the supply-side model, it is assumed that sector 1 is hypothetically extracted, so let $B_{12}=0$. Eq. (10) can be rewritten as:

$$
\left[\begin{array}{ll}
X^{\prime} 1 & X^{\prime} 2
\end{array}\right]=\left[\begin{array}{ll}
X_{1} & X_{2}
\end{array}\right] \times\left[\begin{array}{cc}
B 11 & 0 \\
B 21 & B 22
\end{array}\right]+\left[\begin{array}{ll}
V_{1} & V_{2}
\end{array}\right]
$$

Thus, the difference between Eq. (10) and Eq. (11), that is the forward linkage (FL), can be obtained as: 


$$
F L=\mathrm{V}_{1} \times\left[\left(\mathrm{K}-G_{11}\right) \lambda_{1}{ }^{\prime}+K B_{12} G_{22} \lambda_{2}^{\prime}\right]+V_{2} \times\left[G_{22} B_{21}\left(K-G_{11}\right) \lambda_{1}{ }^{\prime}+G_{22} B_{21} K B_{12} G_{22} \lambda_{2}{ }^{\prime}\right]
$$

where $K$ equals $\left(I-B_{11}-B_{12} G_{22} B_{21}\right)^{-1}$, and $l_{1}^{\prime}$ and $l_{2}$ ' are row summation vectors for $g_{1}$ and $g_{2}$ respectively. The relative forward linkage indicator can be obtained as:

Relative forward linkage indicator $=\frac{F L}{\lambda^{\prime} X} \times 100 \%$

Consequently, the absolute forward linkage indicator can be expressed as:

Absolute forward linkage indicator $=\frac{F L}{x_{i}} \times 100 \%$

\subsection{Internal linkage indicator}

From Eq. (1), let $\mathrm{A}_{11}=0$, then,

$$
\left[\begin{array}{l}
X^{\prime} 1 \\
X^{\prime} 2
\end{array}\right]=\left[\begin{array}{cc}
0 & A 12 \\
A 21 & A 22
\end{array}\right] \times\left[\begin{array}{l}
X^{\prime} 1 \\
X^{\prime} 2
\end{array}\right]+\left[\begin{array}{l}
Y_{1} \\
Y_{2}
\end{array}\right]
$$

The difference between Eq. (1) and Eq. (15), that is the internal linkage (IL), can be obtained as:

$$
I L=\left[\lambda_{1}(\mathrm{H}-\theta)+\lambda_{2} L_{22} A_{21}(H-\theta)\right] \times \mathrm{Y}_{1}+\left[\lambda_{1}(H-\theta) A_{12} L_{22}+\lambda_{2} \mathrm{~L}_{22} A_{21}(H-\theta) A_{12} L_{22}\right] \times Y_{2}
$$

where $\theta=\left(\mathrm{I}-A_{12} L_{22} A_{21}\right)^{-1}$. So, the relative internal linkage indicator can be shown as:

Relative internal linkage indicator $=\frac{I L}{\lambda X} \times 100 \%$

and the absolute internal linkage indicator can be shown as:

Absolute internal linkage indicator $=\frac{I L}{x_{i}} \times 100 \%$

\subsection{Sectoral linkage indicator}

The sectoral linkage indicator represents the linkage between any two sectors. Two questions must be resolved here: one is how to measure this linkage. The other is how to distinguish the directions of the linkage, from the sector $i$ to the sector $j$ or from the sector $j$ to the sector $i$.

\section{(1) Sectoral linkage indicators from sector $i$ to $j$}

It is assumed that the n-sector input-output technical coefficient matrix $A$ has been partitioned into two groups: group $1\left(\hat{g}_{1}\right)$ and group $2\left(\hat{g}_{2}\right)$. The symbol $\hat{g} 1$ is a group that consists of two sectors: sector $i$ and $j$, which are to be extracted from the economy and sector $i$ has relationship with sector $j$. The symbol $\hat{g} 2$ consists of all the remaining sectors of the economy. By extracting $\hat{g} 1$ hypothetically from the economy, the first question mentioned above can be resolved. Theoretically, in the Leontief model, the technical coefficient matrix A is also called direct input coefficient matrix. All column elements of the matrix $A$ represent the direct input from sector $i$ to $j$, that is, the purchases of the $j$ sector from the $i$ sector per monetary unit. Moreover, all column elements of the total input coefficient matrix $L$ represent both direct and indirect flows from sector $i$ to $j$, that is, the effect of one monetary unit change in final demand of the $j$ sector on total 
output of the $i$ sector. Hence, using the Leontief model to measure the sectoral linkage, the linkage direction (from sector $i$ to $j$ ) can be stated. According to the analysis above, the Leontief model can be shown as

$$
\left[\begin{array}{l}
\hat{X}_{1} \\
\hat{X}_{2}
\end{array}\right]=\left[\begin{array}{ll}
\hat{A} 11 & \hat{A} 12 \\
\hat{A} 21 & \hat{A} 22
\end{array}\right] \times\left[\begin{array}{l}
\hat{X}_{1} \\
\hat{X}_{2}
\end{array}\right]+\left[\begin{array}{l}
\hat{Y}_{1} \\
\hat{Y}_{2}
\end{array}\right]
$$

where sub-matrices $\hat{A}_{12}$ and $\hat{A}_{21}$ show the relationships between $\hat{g}_{1}$ and $\hat{g}_{2}$ in production $\hat{A}_{11}$ and $\hat{A}_{22}$ indicate the intra-sectoral connections of $\hat{g}_{1}$ and $\hat{g}_{2}, \hat{X}_{1}$ and $\hat{X}_{2}$ denote the outputs of $\hat{g}_{1}$ and $\hat{g} 2$, and $\hat{Y}_{1}$ and $\hat{Y}_{2}$ denote the final demand of $\hat{g}_{1}$ and $\hat{g} 2$ respectively. Now, let $\hat{\mathrm{A}}_{11}=0$, then

$$
\left[\begin{array}{l}
\hat{X}^{\prime} 1 \\
\hat{X}^{\prime} 2
\end{array}\right]=\left[\begin{array}{cc}
0 & \hat{A} 12 \\
\hat{A} 21 & \hat{A} 22
\end{array}\right] \times\left[\begin{array}{l}
\hat{X}^{\prime} 1 \\
\hat{X}^{\prime} 2
\end{array}\right]+\left[\begin{array}{c}
\hat{Y}^{\prime} 1 \\
\hat{Y}^{\prime} 2
\end{array}\right]
$$

The difference between Eq. (19) and (20) can be expressed as

$$
\left[\begin{array}{c}
\hat{X}_{1} \hat{X}^{\prime} 1 \\
\hat{X}_{2}-\hat{X}^{\prime} 2
\end{array}\right]=\left[\begin{array}{cc}
\hat{H}-(I-\hat{A} 12 \hat{L} 22 \hat{A} 21)^{-1} & {\left[\hat{H}-(I-\hat{A} 12 \hat{L} 22 \hat{A} 21)^{-1}\right] \hat{A} 12 \hat{L} 22} \\
\hat{L} 22 \hat{A} 21\left[\hat{H}-(I-\hat{A} 12 \hat{L} 22 \hat{A} 21)^{-1}\right] & \hat{L} 22 \hat{A} 21\left[\hat{H}-(I-\hat{A} 12 \hat{L} 22 \hat{A} 21)^{-1}\right] \hat{A} 12 \hat{L} 22
\end{array}\right] \times\left[\begin{array}{c}
\hat{Y}_{1} \\
\hat{Y} 2
\end{array}\right]
$$

where $\hat{H}=\left(I-\hat{A}_{11}-\hat{A}_{12} \hat{L}_{22} \hat{A}_{21}\right)^{-1}$, and $\mathrm{L}_{22}=\left(I-\hat{A}_{22}\right)^{-1}$. Then the sectoral linkage from sector $i$ to $j\left(S L_{\mathrm{ij}}\right)$ can be expressed as

$$
\begin{aligned}
& S L_{\mathrm{ij}}=\left[\lambda_{1}\left(\hat{H}-(I-\hat{A} 12 \hat{L} 22 \hat{A} 21)^{-1}\right)+\lambda_{2} \hat{L}_{22} \hat{A}_{21}\left(\hat{H}-(I-\hat{A} 12 \hat{L} 22 \hat{A} 21)^{-1}\right)\right] \times \hat{Y}_{1}+ \\
& \left.\left[\lambda_{1} \hat{H}-(I-\hat{A} 12 \hat{L} 22 \hat{A} 21)^{-1}\right) \hat{A}_{12} \hat{L}_{22} \lambda_{2} L_{22} \hat{A}_{21}\left(\hat{H}-(I-\hat{A} 12 \hat{L} 22 \hat{A} 21)^{-1}\right) \hat{A}_{12} \hat{L}_{22}\right] \times \hat{Y}_{2}
\end{aligned}
$$

So, the relative sectoral linkage indicator (from the sector $i$ to sector $j$ ) can be shown as

Relative sectoral linkage indicator $(i \rightarrow j)=\frac{S L_{i j}}{\lambda X} \times 100 \%$

and the absolute sectoral linkage indicator (from the sector $i$ to sector $j$ ) can be shown as

Absolute sectoral linkage indicator $(i \rightarrow j)=\frac{S L_{i j}}{x_{i}+x_{j}} \times 100 \%$

(2) Sectoral linkage indicators from sector $j$ to $i$

Similarly, using the Ghosh model to measure the sectoral linkage, the linkage direction (from sector $j$ to $i$ ) can be confirmed. In the Ghosh model, the allocation coefficient matrix $B$ is also called direct output coefficient matrix. All row elements of the matrix $B$ represent the direct output from sector $\mathrm{j}$ to sector $\mathrm{i}$, that is, the sales of the $\mathrm{j}$ sector to the $\mathrm{i}$ sector per monetary unit. Moreover, all row elements of the total output coefficient matrix $G$ represent both direct and indirect flows from sector $j$ to $i$, that is, the effect of one monetary unit change in value added of 
the $\mathrm{i}$ sector on total output of the $\mathrm{j}$ sector. So, the Ghosh model can be expressed as:

$$
\left[\begin{array}{ll}
\hat{X}_{1} & \hat{X}_{2}
\end{array}\right]=\left[\begin{array}{ll}
\hat{X}_{1} & \hat{X}_{2}
\end{array}\right] \times\left[\begin{array}{ll}
\hat{B}_{11} & \hat{B}_{12} \\
\hat{B}_{21} & \hat{B}_{22}
\end{array}\right]+\left[\begin{array}{ll}
\hat{V}_{1} & \hat{V}_{2}
\end{array}\right]
$$

where, $\hat{V}_{1}$ and $\hat{V}_{2}$ denote the value added of $\hat{g}_{1}$ and $\hat{g}_{2}$ respectively. $\hat{B}_{11}, \hat{B}_{12}, \hat{B}_{21}$ and $\hat{B}_{22}$ are the partitioned matrixes of the allocation coefficient matrix $B$.

From the supply-side model, it is assumed that $\hat{g} 1$ is hypothetically extracted, so let $\hat{B} 11=0$. Thus, Eq. (25) can be rewritten as:

$$
\left[\begin{array}{ll}
\hat{X}^{\prime} 1 & \hat{X}^{\prime} 2
\end{array}\right]=\left[\begin{array}{ll}
\hat{X}^{\prime} 1 & \hat{X}^{\prime} 2
\end{array}\right] \times\left[\begin{array}{cc}
0 & \hat{B}_{12} \\
\hat{B}_{21} & \hat{B}_{22}
\end{array}\right]+\left[\begin{array}{ll}
\hat{V}_{1} & \hat{V}_{2}
\end{array}\right]
$$

The difference between Eq. (25) and Eq. (26) can be shown as:

$$
\left[\begin{array}{ll}
\hat{X}_{1}-\hat{X}^{\prime} 1 & \hat{X}_{2}-\hat{X}^{\prime} 2
\end{array}\right]=\left[\begin{array}{ll}
\hat{V}_{1} & \hat{V}_{2}
\end{array}\right] \times\left[\begin{array}{cc}
\hat{K}-(I-\hat{B} 12 \hat{G} 22 \hat{B} 21)^{-1} & {\left[\hat{K}-(I-\hat{B} 12 \hat{G} 22 \hat{B} 21)^{-1}\right] \hat{B}_{12} \hat{G} 22} \\
\hat{G} 22 \hat{B} 21\left[\hat{K}-(I-\hat{B} 12 \hat{G} 22 \hat{B} 21)^{-1}\right] & \hat{G} 22 \hat{B} 21\left[\hat{K}-\left(I-\hat{B} 12 \hat{G} 22 \hat{B}_{21}\right)^{-1}\right] \hat{B}_{12} \hat{G} 22
\end{array}\right]
$$

where $\hat{K}=\left(I-\hat{B} 11-\hat{B} 12 \hat{G} 22 \hat{B}_{21}\right)^{-1}$ and $\hat{G} 22=\left(I-\hat{B}_{22}\right)^{-1}$. Consequently, the sectoral linkage from sector $j$ to $i\left(S L_{j i}\right)$ can be expressed as

$$
\begin{aligned}
& S L_{j i}=\hat{V} 1 \times\left[\left(\hat{K}-\left(I-\hat{B} 12 \hat{G} 22 \hat{B}_{21}\right)^{-1}\right) \lambda^{\prime} 1+\left(\hat{K}-(I-\hat{B} 12 \hat{G} 22 \hat{B} 21)^{-1}\right) \hat{B} 12 \hat{G} 22 \lambda^{\prime} 2\right] \\
& \hat{V} 2\left[\hat{G} 22 \hat{B} 21\left(\hat{K}-(I-\hat{B} 12 \hat{G} 22 \hat{B} 21)^{-1}\right) \lambda^{\prime} 1+\hat{G} 22 \hat{B} 21\left(\hat{K}-(I-\hat{B} 12 \hat{G} 22 \hat{B} 21)^{-1}\right) \hat{B} 12 \hat{G} 22 \lambda^{\prime} 2\right]
\end{aligned}
$$

So, the relative sectoral linkage indicator (from the sector $j$ to sector $i$ ) can be shown as

Relative sectoral linkage indicator $(j \rightarrow i)=\frac{S L_{j i}}{\lambda X} \times 100 \%$

and the absolute sectoral linkage indicator (from the sector $j$ to sector $i$ ) can be shown as

$$
\text { Absolute sectoral linkage indicator }(j \rightarrow i)=\frac{S L_{j i}}{\left(x_{j}+x_{i}\right)} \times 100 \%
$$

\section{DATA DESCRIPTION}

The OECD input-output database, which is published by the Economic Analysis and Statistics Division of the OECD, provides appropriate multinational economic data (OECD, 1995). This is the most comprehensive database for comparing the real estate and construction sectors internationally so far (Pietroforte and Gregori 2003; Liu et al., 2005). The OECD input-output database provides input-output data in current and constant prices for ten countries: Australia, Canada, Denmark, France, Germany, Italy, Japan, Netherlands, United Kingdom, and United States. The distinctive nature of this database comprises: (1) the use of a common industrial classification for 36 sectors by following the International Standard Industrial Classification (ISIC) version two, (2) the separation of transaction flows of goods and services into domestically produced and imported, and (3) the inclusion of capital investment flow matrices as supporting tables (OECD, 1995).

Due to limited comparable and available data in the real estate and construction sectors, Germany, Italy and United Kingdom are not considered. The data of France are unavailable 
before the early 1980s. The data from Australia are unavailable before mid-1980s and the data from Netherlands is not available in the late 1980s. In order to avoid the effect of non-uniform inflation rises in the 1970s and 1980s, the data are adopted at constant prices. In addition, the examined period is divided into five comparative periods as shown in Appendix 1: early-1970s (1968-1972), mid/late-1970s (1975-1978), early-1980s (1980-1982), mid-1980s (1985-1986) and late1980s (1989-1990). The 36 sectors used in the OECD input-output table are shown in Appendix 2. Except for Australia and Denmark, whose data are expressed in basic price, all other countries' data are described in producers' price.

\section{EMPIRICAL RESULTS OF OECD COUNTRIES}

Using the proposed framework, the importance of the real estate sector and the quantities relationship between the real estate sector and other sectors can be measured. The developing trends of the real estate sector in different countries can be compared. Based on a good understanding on these linkages, government and businesses can develop their policies and strategies and create a favorable competitive position in the modern economy. Assuming that the real estate sector has been extracted hypothetically from the economic system, the total, backward, forward, internal and sectoral linkages of the real estate sector are calculated, analyzed and compared in sequence.

\subsection{Total linkage indicators of the real estate sector}

Total linkage indicator is one comprehensive measure of the real estate sector's importance to the economy because all connections (forward, backward and internal effects) have been extracted completely (Miller and Lahr, 2001). With the "disappearance" of the real estate sector, the remaining sectors in the economy would have to purchase from overseas and the real estate sector's final demand would have to be satisfied by imports as well. The difference between the outputs before and after the extraction just reflects the importance of the real estate sector. In other words, the total linkage indicator is an integration of the forward, backward and internal effects. The relative total linkage indicators of the real estate sector for the seven selected countries are generated from Eq. (4) and illustrated in Figure 2, which shows the changes of the total real estate linkage relative to the each national economy. The relative total linkage indicators show two distinct groups of countries: Netherlands and Canada with a lower relative total linkage indicator and the remaining countries with higher ones. In economic development, the real estate sector seems to play a more important role in Australia, Denmark, France, Japan and USA than in Netherlands and Canada.

In order to reflect the entire trend and average levels, the arithmetic means of the relative total linkage indicators are calculated and depicted in Figure 2. It can be observed that the values tend to increase over the examined period. In the late $1980 \mathrm{~s}$, the pace of increase is noteworthy in most of the countries. The reason may be due to the increase in the price of real estate in these countries. The increased pattern supports the argument that the role of the real estate sector is growing with economic maturity. However, it has to be noted that the volumes of real estate service are still underestimated because some private brokage are only partially captured by official statistics.

The absolute total linkage indicators of the real estate sector are calculated from Eq. (5) and reported in Table 1, which shows the absolute changes of the total real estate linkage relative to each real estate sector. For example, if the Australian real estate sector is hypothetically removed, the total output in the economy will fall to 86.15 percent of this sector's actual output. 


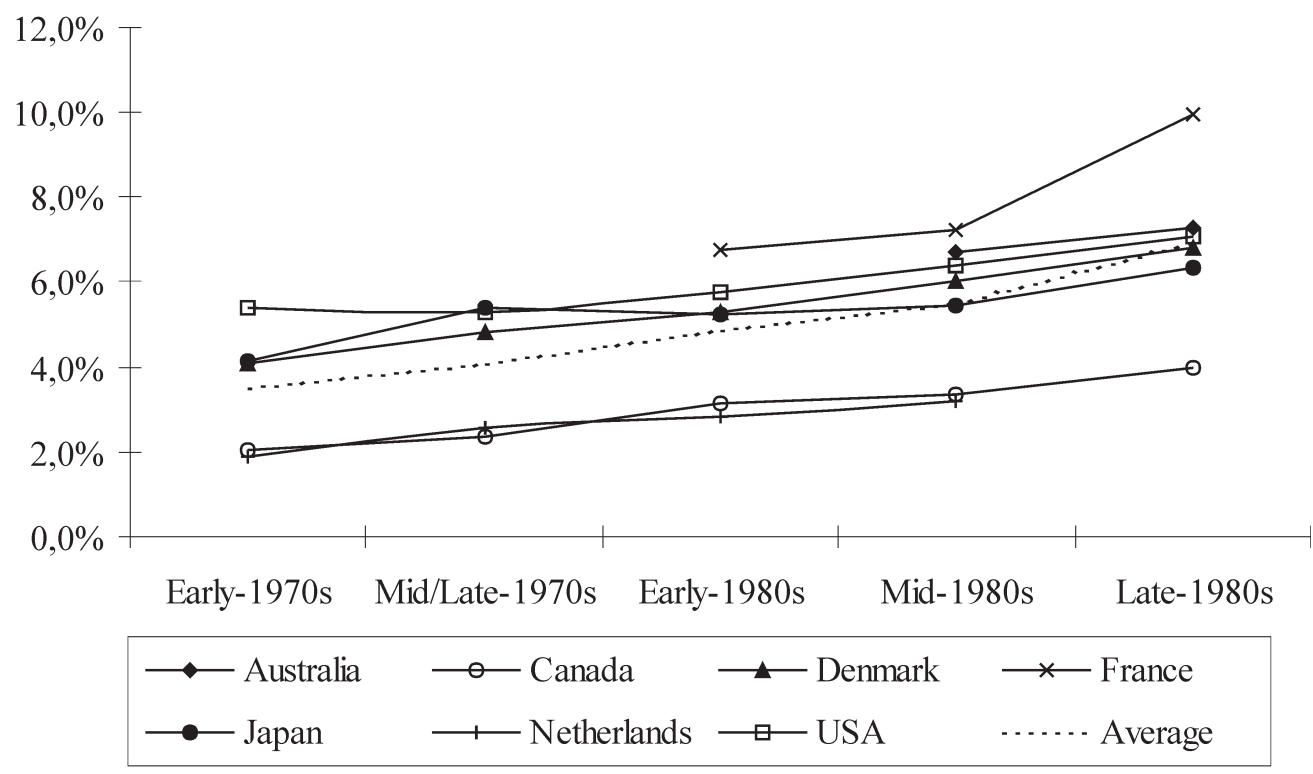

Figure 2. Relative total linkage indicators of the real estate sector

Generally speaking, a higher absolute total linkage indicator represents a higher importance of the real estate sector. In most situations, the absolute linkage is a mirror image of the relative linkage and to some extent the absolute linkages just amplify the magnitude of the relative linkages. However, an extremely high absolute linkage indicator would be an exception. On one hand the extremely high value may indicate a low actual output of the real estate sector (the actual output is a denominator in the formula). On the other hand, it may mean that the real estate sector should play an important role in local economy with an enormous domestic demand. Yet, most of the demands in fact have been met mainly by import due to the low actual output. Canada is a good example. The extremely high value in Canada is due to the fact that the whole real estate sector is monopolised by import service businesses. This just reflects that the local real estate sector plays a weak role in Canada from another angle.

A vertical comparison of the relative total linkage indicator for particular countries is also needed. According to Eq. (4), the relative total linkages of 36 sectors are calculated and ranked for all seven countries, and the rankings of the real estate sector of these countries are reported in

Table 1. Absolute total linkage indicators of the real estate sector

\begin{tabular}{llllll}
\hline & Early-1970s & Mid/Late-1970s & Early-1980s & Mid-1980s & Late -1980s \\
\hline Australia & N/A & N/A & N/A & $86,15 \%$ & $85,64 \%$ \\
Canada & $221,74 \%$ & $202,68 \%$ & $180,07 \%$ & $169,15 \%$ & $169,26 \%$ \\
Denmark & $82,11 \%$ & $83,99 \%$ & $87,39 \%$ & $94,10 \%$ & $99,74 \%$ \\
France & N/A & N/A & $99,72 \%$ & $99,42 \%$ & $119,27 \%$ \\
Japan & $99,52 \%$ & $96,27 \%$ & $93,12 \%$ & $94,31 \%$ & $109,22 \%$ \\
Netherlands & $65,55 \%$ & $71,37 \%$ & $70,90 \%$ & $76,89 \%$ & N/A \\
USA & $80,66 \%$ & $77,04 \%$ & $76,97 \%$ & $99,86 \%$ & $88,67 \%$ \\
\hline
\end{tabular}


Table 2. Except for Canada and Netherlands and Japan in the early-1970s, all values of the relative total linkage of the real estate sector are ranked as the top ten. Specially, the values ranked Australia, France and USA in the top five over the whole examined period. Moreover, a trend of increase of the rankings is apparent and all rankings are increasing between the initial and final stages of the examined period. The ranking differences may be contributed by different industrial structures, relative prices, technology changes and government policies in different countries.

Table 2. Ranks of the relative total linkage indicators of the real estate sectors in each country

\begin{tabular}{llllll}
\hline & Early-1970s & Mid/Late-1970s & Early-1980s & Mid-1980s & Late -1980s \\
\hline Australia & N/A & N/A & N/A & 2 & 2 \\
Canada & 20 & 19 & 14 & 13 & 13 \\
Denmark & 10 & 9 & 9 & 6 & 5 \\
France & N/A & N/A & 3 & 1 & 1 \\
Japan & 12 & 8 & 9 & 5 & 4 \\
Netherlands & 18 & 18 & 16 & 13 & N/A \\
USA & 2 & 4 & 2 & 1 & 1 \\
\hline
\end{tabular}

\subsection{Backward linkage indicators of the real estate sector}

Assuming that all local product inputs of the real estate sector are extracted and all inputs will depend on imports (the forward and internal effects will remain), the backward linkage of a sector reflects this sector's dependence on local inputs that are produced within the production process of the economy. The relative backward linkage indicators of the real estate sector for the seven selected countries are calculated from Eq. (8) and presented in Figure 3. The values are scattered at a low value between $0.5 \%$ and $4 \%$ over the examined period. The relatively lower value is reasonable for the real estate sector because this sector plays a fundamental connecting role in the value chain (Roulac, 1999). A weak backward linkage suggests a strong sectoral independence. On the other hand, a lower value represents a weak economic pull of the real estate sector to the remaining sectors. The backward linkage induces growth through the process of derived demand because the remaining sectors would have to face the losses without the purchase of the real estate sector.

More importantly, the backward linkage indicator is a measure of the degree of the industrialization of the real estate production process and the national technology difference in terms of intermediate and valued added inputs composition (Pietroforte and Gregori, 2003), because it is generally agreed that input-output tables reflect a general equilibrium model of the economy where inputs are allocated according to technological availability (Bon 2000). With a lower relative backward linkage indicator, the real estate sector represents low industrialization and technology levels. However, a slightly upward trend over the entire study period can be seen. In any industry, the progress of technology cannot be stopped.

Compared with Canada and Netherlands, the Australian, Danish, French, Japanese and American real estate sectors show relatively weak economic independences, strong pull effects to the remaining sectors of the economy and higher technology levels. The absolute backward linkage indicators of the real estate sector are calculated from Eq. (9) and reported in Table 3, which shows the absolute change rates of the total output of the real estate sector if the backward effects of this sector are removed from the economy. Except for the early-1970s, the average 


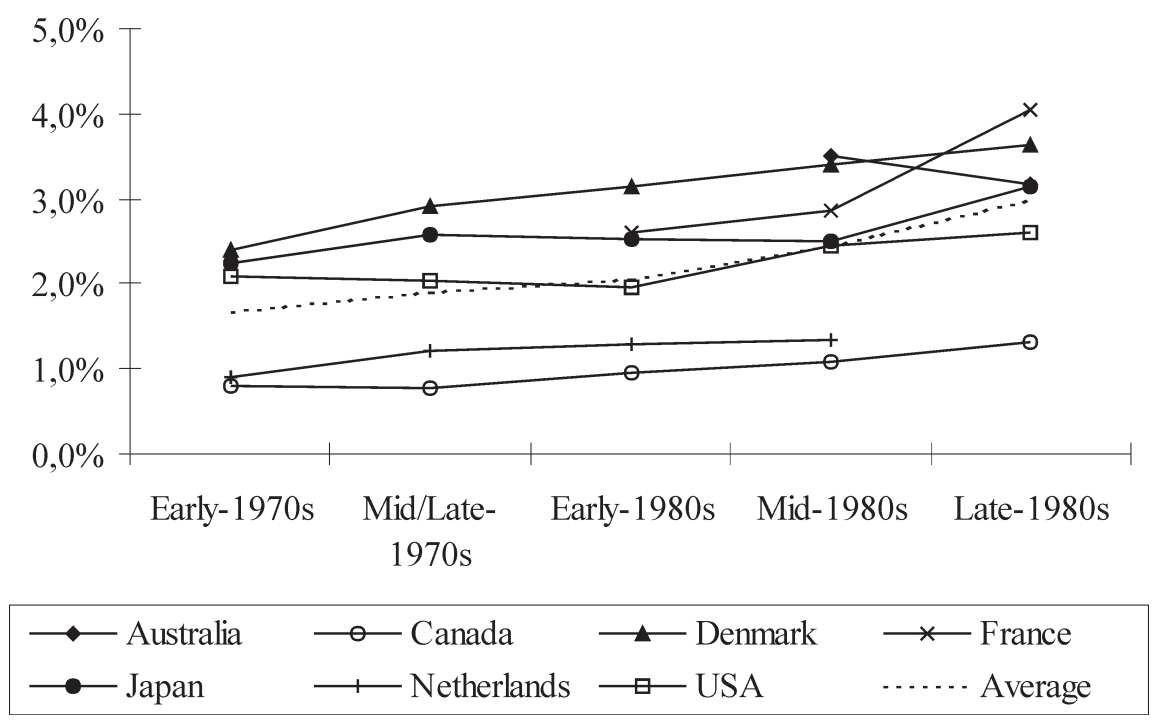

Figure 3. Relative backward linkage indicators of the real estate sector

absolute backward linkage indicators are under 50\%. This indicates that the impact of the backward linkage on this sector is still relatively weak.

Table 3. Absolute backward linkage indicators of the real estate sector

\begin{tabular}{llllll}
\hline & Early-1970s & Mid/Late-1970s & Early-1980s & Mid-1980s & Late-1980s \\
\hline Australia & N/A & N/A & N/A & $44,79 \%$ & $37,37 \%$ \\
Canada & $86,32 \%$ & $68,08 \%$ & $54,33 \%$ & $54,32 \%$ & $55,44 \%$ \\
Denmark & $47,87 \%$ & $50,80 \%$ & $51,61 \%$ & $53,13 \%$ & $53,29 \%$ \\
France & N/A & N/A & $38,29 \%$ & $39,54 \%$ & $48,55 \%$ \\
Japan & $53,44 \%$ & $45,86 \%$ & $44,82 \%$ & $43,40 \%$ & $54,25 \%$ \\
Netherlands & $31,69 \%$ & $33,97 \%$ & $31,98 \%$ & $31,92 \%$ & N/A \\
USA & $31,04 \%$ & $29,80 \%$ & $25,95 \%$ & $38,19 \%$ & $32,52 \%$ \\
\hline Average & $50,07 \%$ & $45,70 \%$ & $41,16 \%$ & $43,61 \%$ & $46,90 \%$ \\
\hline
\end{tabular}

Like the total linkages, the relative backward linkage ranks of the real estate sector are listed in Table 4. Except for Australia and USA, most of countries have a relative lower ranking. However, most of ranks have experienced rise except for Australia. For example the rankings of Japan, France and Denmark rose from 14 to 6, from 9 to 3 and from 11 to 7 respectively between the initial and final stages of the examined period. On one hand, the increasing trend represents a decreasing sectoral independence of the real estate sector and means the real estate sector needs support more and more from other sectors. On the other hand, it means that the real estate sector's ability to pull the rest of the economy is increasing. 
Table 4. Ranks of the relative backward linkage indicators of the real estate sector in each country

\begin{tabular}{llllll}
\hline & Early-1970s & Mid/Late-1970s & Early-1980s & Mid-1980s & Late -1980s \\
\hline Australia & N/A & N/A & N/A & 4 & 5 \\
Canada & 25 & 23 & 23 & 21 & 21 \\
Denmark & 11 & 10 & 8 & 7 & 7 \\
France & N/A & N/A & 9 & 6 & 3 \\
Japan & 14 & 10 & 11 & 6 & 6 \\
Netherlands & 20 & 17 & 15 & 17 & N/A \\
USA & 6 & 8 & 8 & 5 & 5 \\
\hline
\end{tabular}

\subsection{Forward linkage indicators of the real estate sector}

The forward linkage of a sector reflects the dependence of the remaining sectors in the economy on this sector's supplies that are produced within the production process. Assuming that the real estate sector just sells for export, except for deliveries to itself, the difference between the outputs in the reduced case and in the original situation reflects the economic losses of the remaining sectors of the economy without the supply of the local real estate sector. The relative forward linkage indicators of the real estate sector for the seven selected countries are calculated from Eq. (13) and depicted in Figure 4.

The value of the relative forward linkage indicators are stabilising at a higher value compared with the relative backward linkage. A strong forward linkage shows a weak sectoral independence and a strong economic push of the real estate sector. Moreover, the value of the indicator reflects that the proportion of final demand of the real estate sector is larger than its intermediate demand in most selected countries. The main reason seems to be that real estate has a major role in creating demand and attracting the buyer to the distribution system. The arithmetic means of the forward linkage indicators divides these countries into two distinct groups of countries: Denmark, Canada and Netherlands, with a lower relative forward linkage indicator and the remaining countries with higher ones. These differences can be explained in terms of the level of the

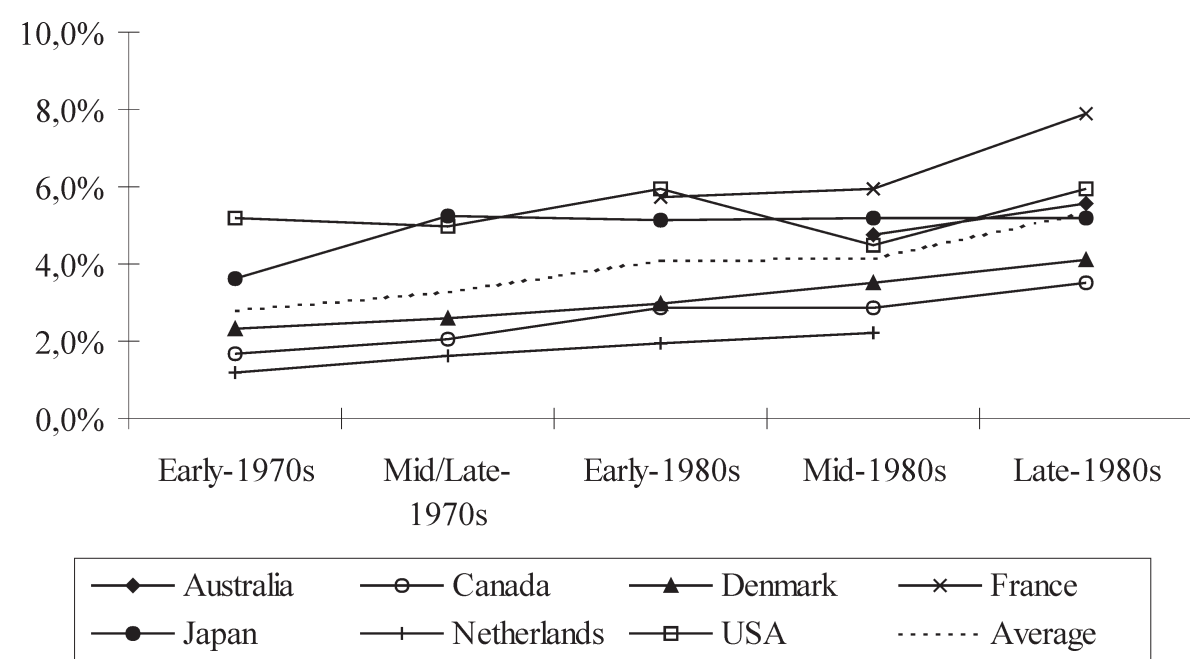

Figure 4. Relative forward linkage indicators of the real estate sector 
intermediate demand in different countries. In Denmark, Canada and the Netherlands, the levels of intermediate demand are very low. The strength of push of the real estate sector in these countries is comparatively weak over the study period. In addition, most of the output of real estate flows into the final demands, that is, private domestic consumption and government consumption. For Australia, France, Japan and USA, the proportion between intermediate demand and final demand tends to be equal. These countries' push strength to economic growth is relatively strong.

The absolute forward linkage indicators of the real estate sector are calculated from Eq. (14) and reported in Table 5, which shows the absolute change rates of the total output of the real estate sector if the forward effects of this sector are extracted from the economy. Compared with the absolute backward linkage indicators, the absolute forward linkage indicator has a higher value, which shows a higher forward effect on the sectoral output.

Table 5. Absolute forward linkage indicators of the real estate sector

\begin{tabular}{llllll}
\hline & Early-1970s & Mid/Late-1970s & Early-1980s & Mid-1980s & Late -1980s \\
\hline Australia & N/A & N/A & N/A & $60,85 \%$ & $65,63 \%$ \\
Canada & $181,42 \%$ & $180,53 \%$ & $165,03 \%$ & $145,77 \%$ & $148,48 \%$ \\
Denmark & $46,76 \%$ & $44,85 \%$ & $49,36 \%$ & $54,72 \%$ & $59,89 \%$ \\
France & N/A & N/A & $84,57 \%$ & $81,67 \%$ & $94,55 \%$ \\
Japan & $86,98 \%$ & $93,40 \%$ & $90,81 \%$ & $89,78 \%$ & $89,40 \%$ \\
Netherlands & $42,26 \%$ & $44,97 \%$ & $48,04 \%$ & $52,79 \%$ & N/A \\
USA & $77,79 \%$ & $72,84 \%$ & $78,80 \%$ & $70,56 \%$ & $74,25 \%$ \\
\hline Average & $75,73 \%$ & $75,66 \%$ & $86,10 \%$ & $79,45 \%$ & $88,70 \%$ \\
\hline
\end{tabular}

The relative forward linkage indicator's ranks of the real estate sector for these countries are presented in Table 6. The relative forward linkages have the highest ranking compared with the relative backward linkages. It seems that the higher rankings in the relative forward linkage are the main reasons for the higher rankings in the relative total linkage. Except for Canada and Netherlands in the early-1970s and the mid/late-1970s, all values of the relative forward linkage of the real estate sector are ranked as the top ten. Especially, the values ranked Australia, France, Japan and USA first in the late-1980s. The higher rankings reflect the strength of the push to economic growth is larger than that of the pull in the real estate sector. It also demonstrates that developing a national economy by promoting the real estate industry is not as effective as developing real estate through promoting the national economy (Liu et al., 2005).

Table 6. Ranks of the relative forward linkage indicators of the real estate sector in each country

\begin{tabular}{llllll}
\hline & Early-1970s & Mid/Late-1970s & Early-1980s & Mid-1980s & Late -1980s \\
\hline Australia & N/A & N/A & N/A & 1 & 1 \\
Canada & 14 & 12 & 7 & 7 & 6 \\
Denmark & 8 & 8 & 7 & 3 & 3 \\
France & N/A & N/A & 1 & 1 & 1 \\
Japan & 7 & 4 & 4 & 1 & 1 \\
Netherlands & 13 & 10 & 9 & 7 & N/A \\
USA & 2 & 2 & 1 & 1 & 1 \\
\hline
\end{tabular}




\subsection{Internal linkage indicators of the real estate sector}

Assuming that the real estate sector's intra-sectoral shipments are eliminated, the internal linkage of a sector reflects the interrelationship of the sub-sectors within the real estate sector. The real estate sector mainly comprises the residential and commercial real estate services. The residential real estate sub-sector supplies living accommodations for the commercial sub-sector, whereas the commercial sub-sector supplies few services for the residential real estate sub-sector. The relationships between these two sectors are relatively loose.

According to Eq. (17), the relative internal linkage indicators are described in Figure 5, which displays three characteristics. Firstly, the real estate sectors have low relative internal linkage indicators, which are all under $1.6 \%$ relative to the entire economy. Secondly, all values present an increasing pattern, which may be due to the increasing price over the examined period. Thirdly, the differences among countries are obvious. For example, France had an extremely high value whereas Netherlands had a very low value. The differences may be contributed by different economic developing levels, relative prices, and government policies in different countries. The relative prices and government policies differences in different economic developing stages definitely affect the interflow between the residential and commercial real estate sub-sectors.

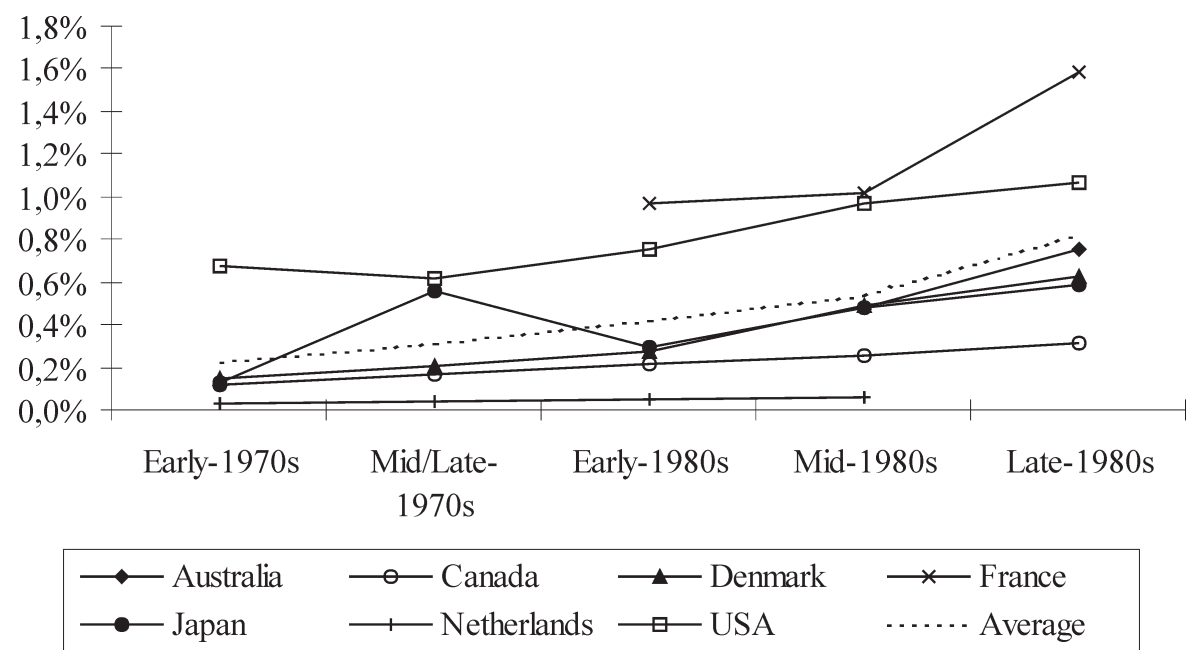

Figure 5. Relative internal linkage indicators of the real estate sector

The absolute internal linkage indicators of the real estate sector are calculated from Eq. (18) and presented in Table 7, which shows the absolute change rates of the total output of the real estate sector if the internal effects of this sector are extracted from the economy. A higher value presents a higher absolute internal linkage. Obviously, the internal flows between the sub-sectors are weak even relative to this sector itself in seven countries. However, in some developing countries, the absolute internal linkage indicator may be higher than the developed countries. One reason is that the increasing commercial real estate market in the developing countries may need more residential services than the developed countries. As expected, the relative internal linkages have a low ranking as reported in Table 8. Compared with other sectors, the low ranking just reflects the industry characteristics of the real estate sector. 
Table 7. Absolute internal linkage indicators of the real estate sector

\begin{tabular}{llllll}
\hline & Early-1970s & Mid/Late-1970s & Early-1980s & Mid-1980s & Late-1980s \\
\hline Australia & N/A & N/A & N/A & $6,16 \%$ & $8,88 \%$ \\
Canada & $12,71 \%$ & $14,21 \%$ & $12,37 \%$ & $12,79 \%$ & $13,39 \%$ \\
Denmark & $3,03 \%$ & $3,65 \%$ & $4,44 \%$ & $7,71 \%$ & $9,20 \%$ \\
France & N/A & N/A & $14,24 \%$ & $13,99 \%$ & $18,95 \%$ \\
Japan & $3,15 \%$ & $9,91 \%$ & $5,21 \%$ & $8,31 \%$ & $10,04 \%$ \\
Netherlands & $0,89 \%$ & $1,15 \%$ & $1,31 \%$ & $1,41 \%$ & N/A \\
USA & $10,11 \%$ & $8,95 \%$ & $9,95 \%$ & $15,14 \%$ & $13,34 \%$ \\
\hline Average & $5,98 \%$ & $7,57 \%$ & $7,92 \%$ & $9,36 \%$ & $12,30 \%$ \\
\hline
\end{tabular}

Table 8. Ranks of the relative internal linkage indicators of the real estate sector in each country

\begin{tabular}{llllll}
\hline & Early-1970s & Mid/Late-1970s & Early-1980s & Mid-1980s & Late -1980s \\
\hline Australia & N/A & N/A & N/A & 9 & 6 \\
Canada & 25 & 22 & 17 & 17 & 17 \\
Denmark & 20 & 18 & 15 & 11 & 11 \\
France & N/A & N/A & 9 & 8 & 4 \\
Japan & 23 & 11 & 17 & 12 & 12 \\
Netherlands & 27 & 27 & 28 & 29 & N/A \\
USA & 8 & 8 & 8 & 3 & 2 \\
\hline
\end{tabular}

\subsection{Sectoral linkage indicators between real estate and construction sectors}

Assuming that the flows between the real estate sector and a specific sector are eliminated, the sectoral linkage indicator reflects the interrelationship of the real estate sector and the specific sector in an economy. This section discusses the sectoral linkage between the real estate and construction sectors in detail. The construction sector plays an important role in the development strategy of any country (Lopes, 1998). As one of the largest consumers of the construction sector, the inter-sectoral flows between these two sectors are varied and complex and it is important to determine the quantitative relationships between them in modern economics. Considering the directions, the relative sectoral linkage indicator can be divided into two groups: one is the linkage from the construction sector to the real estate sector, which is calculated from Eq. (23) and described in Figure 6. The other is the linkage from the real estate sector to the construction sector, which is from Eq. (29) and illustrated in Figure 7.

As expected, the relative linkages from construction to real estate are larger than that from real estate to construction. The real estate sector supplies various kinds of services for the construction sector, such as brokerage, plant location, layout and lease, procurement decision, and so on. One of the main assignments of the real estate sector is to make decisions for plant location of construction business concerning the country, region, submarket and site. Another concerned is size of facility, layout, lease or buy decision and brokerage.

What is more, the real estate sector also influences construction manufacture access including the location of the manufacturer's showrooms, access to shows that display construction merchandise and catalogues. Generally, the real estate sector as supplier just plays a service delivery role in the value chain of the construction sector. On the other hand, the construction sector is the one of largest suppliers of the real estate and most intermediate goods and services produced 


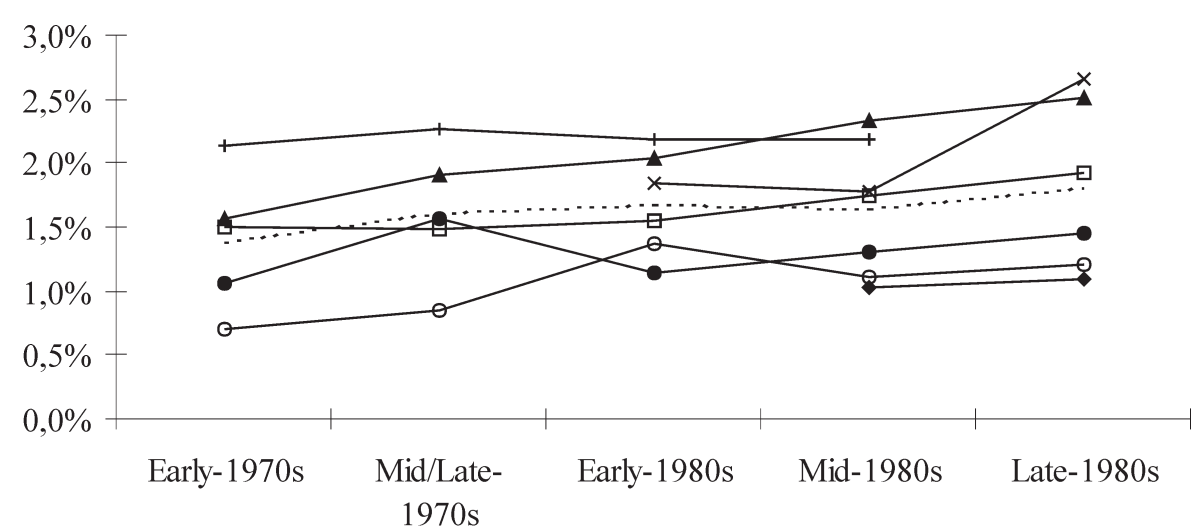

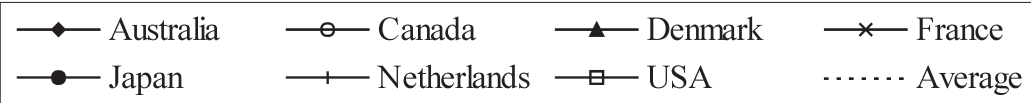

Figure 6. Relative sectoral linkage indicators from construction to real estate

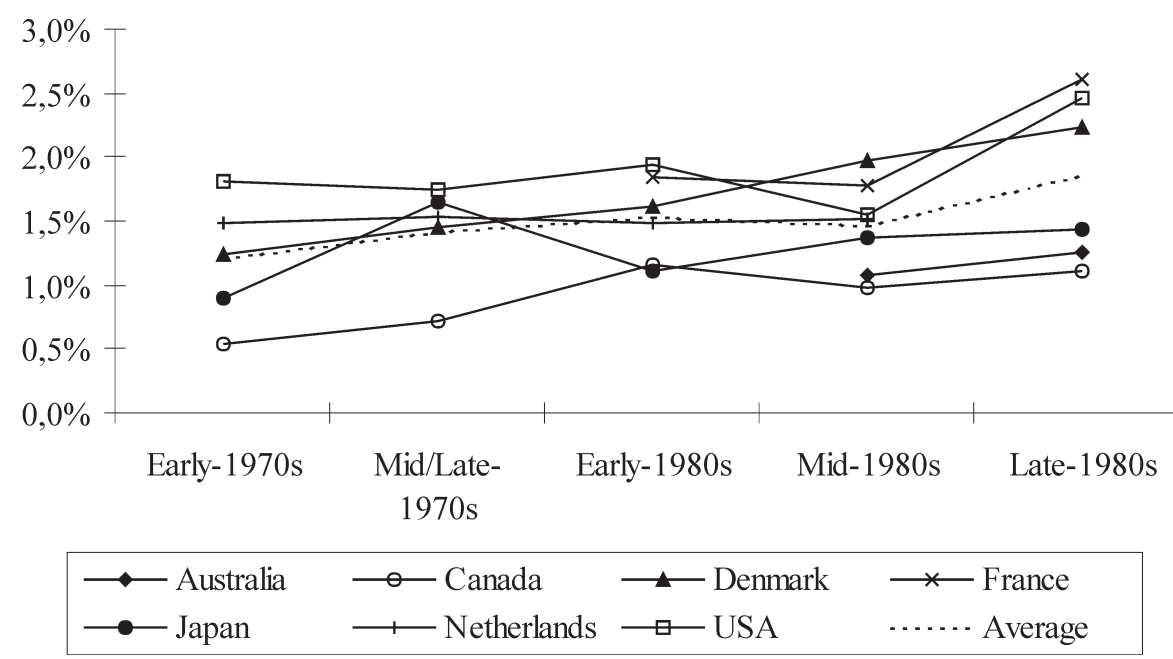

Figure 7. Relative sectoral linkage indicators from real estate to construction

by the maintenance and repair construction sub-sector go to the real estate sector. This explains why linkages from construction to real estate are larger than that from real estate to construction.

However, it can be stated that the economic development in a developed country has been characterized by two main trends: the decreasing economic importance of the construction industry and the progressive increasing services of the real estate sector. In this regard, the two main trends are just reflected by the average values of the relative sectoral linkage indicators in Figure 6 and 7. Obviously, the mean of the sectoral linkage indicators from the construction sector to the real estate sector is flatter than the mean of the sectoral linkage indicators from the real estate sector to the construction sector over the examined period. The average values in Figure 7 
indicate a higher acceleration of the outputs from the real estate sector to the construction sector.

The two kinds of absolute sectoral linkage indicators are calculated from Eqs. (24) and (30) and presented in Table 9, which shows the absolute change rates of the total output of the real estate and construction sectors if the sectoral effects of these two sectors are extracted from the economy. Except for the late-1980s, the average absolute sectoral linkage from construction to real estate is higher than that from real estate to construction. The sectoral linkages between the real estate and construction sectors are ranked and reported in Table 10. The average absolute sectoral

Table 9. Absolute sectoral linkage indicators

\begin{tabular}{|c|c|c|c|c|c|c|}
\hline & & Early-1970s & Mid/Late-1970s & Early-1980s & Mid-1980s & Late-1980s \\
\hline \multirow{2}{*}{ Australia } & $\Rightarrow$ & \multirow{2}{*}{ N/A } & \multirow{2}{*}{ N/A } & \multirow{2}{*}{ N/A } & $7,64 \%$ & $7,70 \%$ \\
\hline & $\Leftarrow$ & & & & $7,97 \%$ & $8,87 \%$ \\
\hline \multirow{2}{*}{ Canada } & $\Rightarrow$ & $8,03 \%$ & $9,86 \%$ & $15,07 \%$ & $13,25 \%$ & $13,50 \%$ \\
\hline & $\Leftarrow$ & $6,26 \%$ & $8,32 \%$ & $12,71 \%$ & $11,75 \%$ & $12,43 \%$ \\
\hline \multirow{2}{*}{ Denmark } & $\Rightarrow$ & $12,38 \%$ & $16,00 \%$ & $17,74 \%$ & $21,13 \%$ & $22,33 \%$ \\
\hline & $\Leftarrow$ & $9,78 \%$ & $12,20 \%$ & $14,15 \%$ & $17,80 \%$ & $19,82 \%$ \\
\hline \multirow{2}{*}{ France } & $\Rightarrow$ & \multirow{2}{*}{ N/A } & \multirow{2}{*}{ N/A } & $15,03 \%$ & $14,90 \%$ & $19,94 \%$ \\
\hline & $\Leftarrow$ & & & $15,07 \%$ & $14,92 \%$ & $19,62 \%$ \\
\hline \multirow{2}{*}{ Japan } & $\Rightarrow$ & $9,04 \%$ & $11,99 \%$ & $9,16 \%$ & $11,31 \%$ & $11,77 \%$ \\
\hline & $\Leftarrow$ & $7,77 \%$ & $12,61 \%$ & $9,01 \%$ & $11,93 \%$ & $11,64 \%$ \\
\hline \multirow{2}{*}{ Netherlands } & $\Rightarrow$ & $22,48 \%$ & $23,59 \%$ & $23,02 \%$ & $23,44 \%$ & \multirow{2}{*}{ N/A } \\
\hline & $\Leftarrow$ & $15,73 \%$ & $16,06 \%$ & $15,65 \%$ & $16,27 \%$ & \\
\hline \multirow{2}{*}{ USA } & $\Rightarrow$ & $12,27 \%$ & $12,69 \%$ & $12,52 \%$ & $16,07 \%$ & $15,54 \%$ \\
\hline & $\Leftarrow$ & $14,90 \%$ & $14,85 \%$ & $15,80 \%$ & $14,22 \%$ & $19,85 \%$ \\
\hline \multirow{2}{*}{ Average } & $\Rightarrow$ & $12,84 \%$ & $14,82 \%$ & $15,42 \%$ & $15,39 \%$ & $15,13 \%$ \\
\hline & $\Leftarrow$ & $10,89 \%$ & $12,81 \%$ & $13,73 \%$ & $13,55 \%$ & $15,37 \%$ \\
\hline
\end{tabular}

$\Rightarrow$ denotes the linkage from the construction sector to the real estate sector.

$\Leftarrow$ denotes the linkage from the real estate sector to the construction sector.

Table 10. Ranks of relative sectoral linkage indicators

\begin{tabular}{|c|c|c|c|c|c|c|}
\hline & & Early-1970s & Mid/Late-1970s & Early-1980s & Mid-1980s & Late-1980s \\
\hline \multirow{2}{*}{ Australia } & $\Rightarrow$ & \multirow{2}{*}{ N/A } & \multirow{2}{*}{ N/A } & \multirow{2}{*}{ N/A } & 12 & 17 \\
\hline & $\Leftarrow$ & & & & 15 & 21 \\
\hline \multirow{2}{*}{ Canada } & $\Rightarrow$ & 13 & 7 & 6 & 8 & 7 \\
\hline & $\Leftarrow$ & 13 & 10 & 6 & 9 & 11 \\
\hline \multirow{2}{*}{ Denmark } & $\Rightarrow$ & 5 & 4 & 3 & 3 & 1 \\
\hline & $\Leftarrow$ & 7 & 4 & 4 & 5 & 4 \\
\hline \multirow{2}{*}{ France } & $\Rightarrow$ & \multirow{2}{*}{ N/A } & \multirow{2}{*}{ N/A } & 11 & 10 & 8 \\
\hline & $\Leftarrow$ & & & 12 & 13 & 11 \\
\hline \multirow{2}{*}{ Japan } & $\Rightarrow$ & 8 & 5 & 9 & 11 & 11 \\
\hline & $\Leftarrow$ & 9 & 8 & 10 & 10 & 14 \\
\hline \multirow{2}{*}{ Netherlands } & $\Rightarrow$ & 2 & 2 & 3 & 3 & \multirow{2}{*}{ N/A } \\
\hline & $\Leftarrow$ & 3 & 4 & 3 & 4 & \\
\hline \multirow{2}{*}{ USA } & $\Rightarrow$ & 8 & 9 & 10 & 11 & 8 \\
\hline & $\Leftarrow$ & 11 & 11 & 12 & 11 & 11 \\
\hline
\end{tabular}

$\Rightarrow$ denotes the linkage from the construction sector to the real estate sector.

$\Leftarrow$ denotes the linkage from the real estate sector to the construction sector. 
linkage from construction to real estate has a higher ranking than that from real estate to construction. Generally, input and output of real estate focus mainly on the service, construction, and wholesale and retail trade sectors.

In different countries, the consumption and output of the real estate sector are slightly different. In Australia, inputs of the real estate sector focuses mainly on the service, construction, and wholesale and retail trade sectors. The output focus is not only on the above sectors, but also on the agriculture and mining sectors. In USA, the consumption structure of the real estate sector is the same as in Australia, but the output structure of the real estate sector is somewhat different. In other countries, the same model also can be inspected. The interrelationship among the real estate sector and other sectors is determined by the characteristics of real estate services. Except for agriculture, forestry and fishery, mining, and quarrying sectors, the remaining sectors in the national economy are easily affected by the real estate sector, and these sectors have a significant effect on the real estate sector as well.

\section{CONCLUSIONS}

This paper proposed a linkage measure framework to explore the linkages between the real estate sector and other sectors using the HEM. The relative linkage indicates the percentage decrease in economy-wide outputs caused by the extraction of real estate and the absolute linkage is termed to indicate an absolute change in sectional outputs caused by the extraction. Four extraction structures are adopted to formulate the total, backward, forward and internal linkage indicators and one structure is developed further to formulate the sectoral linkage indicator of the real estate sector, which indicate the linkage between the real estate and construction sectors. In most situations, the absolute linkage is a mirror image of the relative linkage and to some extent the absolute linkages just amplify the magnitude of the relative linkages. This framework also can be employed in other sectors to explore the linkages.

Empirical results show an increasing trend of these linkages in real estate, which confirms the increasing role of the real estate sector with economic maturity over the examined period. In economic development, the real estate sector seems to play a more important role in Australia, Denmark, France, Japan and USA than in Netherlands and Canada. The value of the relative backward linkage indicators are scattered at a low value because this sector plays a fundamental connecting role in the value chain, which suggests a strong sectoral independence and a weak economic pull of the real estate sector to the remaining sectors. Whereas, the value of the relative forward linkage indicators are stabilising at a higher value, which shows a weak sectoral independence and a strong economic push of the real estate sector because real estate has a major role in creating demand and attracting the buyer to the distribution system. What is more, a low relative internal linkage indicator means the relationships between these two sectors are relatively loose. The reason may be the residential real estate sub-sector supplies living accommodations for the commercial sub-sector, whereas the commercial sub-sector supplies few services for the residential real estate sub-sector.

Considering the directions, the relative sectoral linkage indicator can be divided into two groups: one is the linkage from the construction sector to the real estate sector. The other is the linkage from the real estate sector to the construction sector. The real estate sector as supplier plays a service delivery role in the value chain of the construction sector. On the other hand, the construction sector is the one of largest suppliers of real estate and most intermediate goods and services produced by the maintenance and repair construction sub-sector go to the real estate sector. This explains why the relative linkages from construction to real estate are larger than 
that from real estate to construction.

The most important application of this framework is to aid government and businesses developing their policies and strategies and create a favorable competitive position in the modern economy. However, it has to be mentioned that pure input-output based linkage has short-comings for identifying core relations in economic systems. Some external data sources, such as research and development data, patent data, fund and knowledge flows and so on, have been used with the input-output table in recent research. Further studies will focus on these fields and the HEM could be more powerful to measure the linkages of the real estate sector.

\section{REFERENCES}

Bon, R. (1988) Direct and indirect resource utilisation by the construction sector: the case of the USA since World War II. Habitat International, 12(1), p. 49-74.

Bon, R. (2000) Economic Structure and Maturity: Collected Papers in Input-output Modelling and Applications, England, Aldershot: Ashgate.

Cai, J. and Leung, P. (2004) Linkage measures: a revisit and a suggested alternative. Economic Systems Research, 16(1), p. 65-85.

Cella, G. (1984) The input-output measurement of interindustry linkages. Oxford Bulletin of Economics and Statistics, 46, p. 73-84.

Chenery, H. B. and Watanabe, T. (1958) International comparison of the structure of production. Econometrica, 26, p. $487-521$.

Clements, B. J. (1990) On the decomposition and normalization of interindustry linkages. Economics Letters, 33, p. 337-340.

Dietzenbacher, E. and Van der Linden, J. A. (1997) Sectoral and spatial linkages in the EC production structure. Journal of Regional Science, 37, p. 235-257.

Duarte, R., Sanchez-Choliz, J. and Bielsa, J. (2002) Water use in the Spanish economy: an input-output approach. Ecological Economics, 43, p. 71-85.

Ghosh, A. (1958) Input-output approach to an allocation system. Economica, 25, p. 58-64.

Hirschman, A. O. (1958) The Strategy of Economic Development. New Haven: Yale University Press.

Hoen, A. R. (2002) Identifying linkages with a cluster-based methodology. Economic Systems Research, 14(2), p. $131-146$.

Lean, C. (2001) Empirical tests to discern linkages between construction and other economic sectors in Singapore. Construction Management and Economics, 19(4), p. 355-363.

Leontief, W. (1936) Quantitative input-output relations in the economic systems of the United States. Review of Economics and Statistics, 18, p. 105-125.

Liu, C. and Song, Y. (2004) Comparison of multifactor productivity indicators for real estate sectors using the OECD input-output database. Pacific Rim Property Research Journal, 10(4), p. 487-507.

Liu, C., Song, Y. and Langston, C. (2005) Economic indicator comparisons of multinational real estate sectors using the OECD input-output database. The International Journal of Construction Management, $5(1)$, p. 59-75.

Lopes, J. (1998) The construction industry and macroeconomy in sub-Saharan africa post 1970. Construction Management and Economics, 16(6), p. 637-649.

Miller, R. E. and Blair, P. D. (1985) Input-Output Analysis: Foundations and Extensions, Englewood, Cliffs, New Jersey: Prentice Hall.

Miller, R. E. and Lahr, M. L. (2001) A Taxonomy of Extractions, in: Regional Science Perspectives in Economic Analysis: A Festschrift in Memory of Benjamin H. Stevens, Lahr, M. L. and Miller, R. E. (eds.), Amsterdam: Elsevier Science, p. 407-441. 
OECD. (1995) The OECD input-output database. OECD, New York.

Pagliari, J. L., Webb, J. R., Canter, T. A. and Lieblich, F. (1997) A fundamental comparison of international real estate returns. Journal of Real Estate Research, 13(3), p. 317-347.

Pietroforte, R., Bon, R. and Gregori, T. (2000) Regional development and construction in Italy: an inputoutput analysis, 1959-1992. Construction Management and Economics, 18(2), p. 151-159.

Pietroforte, R. and Gregori, T. (2003) An input-output analysis of the construction sector in highly developed economies. Construction Management and Economics, 21(3), p. 319-327.

Rasmussen, P. (1956) Studies in Inter-Sectoral Relations, Copenhagen: Einar Harks.

Roulac, S. E. (1996) The strategic real estate framework: processes, linkages, decisions. Journal of Real Estate Research, 12(3), p. 323-346.

Roulac, S. E. (1999) Real estate value chain connections: tangible and transparent. Journal of Real Estate Research, 17(3), p. 387-404.

Song, Y., Liu, C. and Langston, C. (2004) Economic analyses on multinational real estate and construction sectors. The 29th Annual Meeting of Australian University Building Education Association, (CD-ROM), Newcastle, p. 303-320.

$\mathrm{Su}, \mathrm{K}$., Lin, C. and Wang, M. (2003) Taiwanese construction sector in a growing 'maturity' economy, 19641999. Construction Management and Economics, 21(7), p. 719-728.

Tse, Y. R. (1994). Real Estate Economics: Theory and Policy with Reference to Hong Kong, Singapore and Taiwan, Hong Kong: EIA Publish.

Yue, G. and Andreosso-O’Callaghan, B. (2004) Intersectional linkages and key sectors in China, 1987-1997. Asian Economic Journal, 18(21), p. 165-183.

\section{SANTRAUKA}

\section{SĄSAJŲ VERTINIMO STRUKTŪRA NEKILNOJAMOJO TURTO SEKTORIUJE}

\section{Yu SONG, Chunlu LIU, Craig LANGSTON}

Susiejimas yra vienas svarbiausių veiksnių siekiant igyti pranašumą konkurencijoje. Informacija apie sąsajas yra labai svarbi norint suprasti ekonomikos struktūrą, kuri savo ruožtu yra svarbi formuluojant pramonės politiką ir verslo strategijas. Hipotetinio išskyrimo metodas taikomas vertinant sąsajas, hipotetiškai išskiriant sektoriu iš ekonominès sistemos. Ankstesniuose tyrinėjimuose vidinės sąsajos (sąsajos sektoriaus viduje) ir sektorių tarpusavio sąsajos (sąsajos tarp dviejų sektorių) būdavo ignoruojamos, be to, nebuvo visa apimančios struktūros, skirtos atskiro sektoriaus sąsajoms vertinti. Remiantis neseniai paskelbtais Ekonominio bendradarbiavimo organizacijos duomenų bazės pirkimo ir pardavimo duomenimis, esant pastovioms kainoms darbo tikslas - ịveikti šiuos du trūkumus ir kartu pasiūlyti sąsajų vertinimo struktūrą siekiant ištirti sąsajas tarp nekilnojamojo turto ir kitų sektorių naujų aspektų kontekste. İvardytos santykinės ir absoliučios sąsajos bei suformuluoti bendrieji, atgaliniai, būsimieji, vidiniai ir sektorių sąsajų indikatoriai, skirti tirti nekilnojamojo turto sektoriaus sąsajoms visomis kryptimis. Empiriniai tyrinejjimų rezultatai rodo stiprèjančią šių sąsajų tendenciją, patvirtinančią vis didejjantị nekilnojamojo turto sektoriaus vaidmenį vystantis ekonomikai tiriamuoju laikotarpiu. Šią metodinę struktūrą taip pat galima taikyti ir kituose sektoriuose. 
APPENDIX 1. OECD input-output table coverage

\begin{tabular}{llllll}
\hline & Early-1970s & Mid/Late-1970s & Early-1980s & Mid-1980s & Late -1980s \\
\hline Australia & N/A & N/A & N/A & 1986 & 1989 \\
Canada & 1971 & 1976 & 1981 & 1986 & 1990 \\
Denmark & 1972 & 1977 & 1980 & 1985 & 1990 \\
France & N/A & N/A & 1980 & 1985 & 1990 \\
Japan & 1970 & 1975 & 1980 & 1985 & 1990 \\
Netherlands & 1972 & 1977 & 1981 & 1986 & N/A \\
USA & 1972 & 1977 & 1982 & 1985 & 1990 \\
\hline
\end{tabular}

(Source: OECD, 1995)

APPENDIX 2. OECD sectoral classification

\begin{tabular}{ll}
\hline No. & Sector \\
\hline 1 & Agriculture, forestry and fishery \\
2 & Mining and quarrying \\
3 & Food, beverages and tobacco \\
4 & Textiles, apparel and leather \\
5 & Wood products and furniture \\
6 & Paper, paper products and printing \\
7 & Industrial chemicals \\
8 & Drugs and medicines \\
9 & Petroleum and coal products \\
10 & Rubber and plastic products \\
11 & Non-metallic mineral products \\
12 & Iron and steel \\
13 & Non-ferrous metals \\
14 & Metal products \\
15 & Non-electrical machinery \\
16 & Office and computing machinery \\
17 & Electric apparatus \\
18 & Radio, TV and communication equipment \\
19 & Shipbuilding and repairing \\
20 & Other transport \\
21 & Motor vehicles \\
22 & Aircraft \\
23 & Professional goods \\
24 & Other manufacturing \\
25 & Electricity, gas and water \\
26 & Construction \\
27 & Wholesale and retail trade \\
28 & Restaurants and hotels \\
29 & Transport and storage \\
30 & Communication \\
31 & Finance and insurance \\
32 & Real estate and business services \\
33 & Community, social and personal service \\
34 & Producers of government services \\
35 & Other producers \\
36 & Statistical discrepancy \\
\hline & \\
\end{tabular}

(Source: OECD, 1995) 